\title{
Relationship between 18F-FDG PET/CT radiometabolic markers and EGFR mutation, positive ALK Expression in patients with non-small cell lung cancer
}

\author{
Mine $\operatorname{GAYAF}^{\mathbf{1}}(\mathrm{ID})$ \\ Ceyda $\operatorname{ANAR}^{2}$ (ID) \\ Nimet $\operatorname{AKSEL}^{\mathbf{1}}(\mathrm{ID})$ \\ Ahmet Emin \\ ERBAYCU $^{1}(I D)$ \\ Hakan KOPORAL ${ }^{1}($ ID)
}

${ }^{1}$ Clinic of Chest Diseases, Health Sciences University İzmir Dr. Suat Seren Chest Diseases and Chest Surgery Training and Research Hospital, İzmir, Turkey

${ }^{1}$ Sağıık Bilimleri Üniversitesi Izmir Dr. Suat Seren Gögüs Hastalıkları ve Cerrahisi Ĕgitim ve Araştırma Hastanesi, Göğüs Hastalıkları Kliniği, izmir, Türkiye

${ }^{2}$ Clinic of Chest Diseases, İzmir Katip Çelebi University Faculty of Medicine, Atatürk Training and Research Hospital, İzmir, Turkey

2 Izmir Katip Çelebi Üniversitesi Tıp Fakültesi, Atatürk Eğitim ve Araştırma Hastanesi, Göğüs Hastalıkları Kliniği, Izmir, Türkiye
Cite this article as: Gayaf $M$, Anar $C$, Aksel $N$, Erbaycu AE, Koporal H. Relationship between 18FFDG PET/CT radiometabolic markers and EGFR mutation, positive ALK Expression in patients with non-small cell lung cancer Tuberk Toraks 2021;69(4):437-448.

\section{Yazışma Adresi (Address for Correspondence)}

\section{Dr. Ceyda ANAR}

Clinic of Chest Diseases,

İzmir Katip Çelebi University

Faculty of Medicine, Atatürk Training and

Research Hospital,

IZMIR - TURKEY

e-mail: drceydaanar@hotmail.com

\footnotetext{
CCopyright 2021 by Tuberculosis and Thorax.
}

Available on-line at www.tuberktoraks.org.com

\section{ABSTRACT}

Relationship between 18F-FDG PET/CT radiometabolic markers and EGFR mutation, positive ALK Expression in patients with non-small cell lung cancer

Introduction: The aim of this study was to evaluate the association between the presence of EGFR mutations, ALK rearrangement and the standardized uptake value (SUV) of 18F-fluoro-2-deoxy-glucose (18F-FDG) by PET/CT imaging in patients with NSCLC.

Materials and Methods: We retrospectively reviewed NSCLC patients, who underwent EGFR mutation, ALK rearrangement testing and pre-treatment PET/ $C T$. The relationships of EGFR mutation, ALK rearrangement with patient characteristics and three parameters based on 18F-FDG PET/CT, including the maximal standard uptake value (SUVmax) of the primary tumour (tSUVmax), lymph node (nSUVmax) and distant metastasis (mSUVmax) were evaluated.

Results: EGFR mutations were found more frequently in females and nonsmokers. TSUVmax was the only PET parameter that was lower in EGFRpositive patients than in EGFR-negative patients ( $8.7 \mathrm{vs}$. 11), with a $p$ value of 0.032 . There were no differences between nSUVmax and mSUVmax results and EGFR mutation. tSUVmax, nSUVmax and mSUVmax were not significantly different between ALK positive and ALK negative groups in NSCLC. The presence of pleural fluid at the time of diagnosis was significantly associated with positive ALK expression.

Conclusion: We showed that low ISUVmax and primary tumour diameter were associated with mutant EGFR status and could be evaluated with other 
clinical factors to increase the discrimination in EGFR mutation status in some NSCLC patients without EGFR testing. There is a correlation between ALK positivity and the presence of pleural fluid. We also noted that the ALK positivity might be only in the adenocarcinoma group and at a younger age.

Key words: Epidermal growth factor receptor; anaplastic lymphoma kinase; mutation; non-small cell lung cancer; positron emission tomography

\section{ÖZ}

Küçük hücreli dışı akciğer kanserli hastalarda 18F-FDG PET/CT radyometabolik belirteçler ile EGFR mutasyonu, pozitif ALK ekspresyonu arasındaki ilişki

Giriş: Bu çalışmanın amacı, Küçük Hücreli Dışı akciğer Kanseri hastalarında EGFR mutasyonun varlı̆̆ı, ALK yeniden düzenlenmesi ile PET/BT'de 18F-floro-2-deoksi-glukozun (18F-FDG) standardize uptake değeri (SUV) arasındaki ilişkiyi değerlendirmektir.

Materyal ve Metod: EGFR mutasyonu, ALK yeniden düzenleme testi ve tedavi öncesi PET/CT uygulanan NSCLC hastalarını retrospektif olarak inceledik. EGFR mutasyonu, ALK yeniden düzenlemesi ile hasta özellikleri ve maksimum standart uptake değeri dahil $18 F$ FDG PET/CT'ye dayalı üç parametre arasındaki ilişkiler Primer tümör (tSUVmax), lenf nodu (nSUVmax) ve uzak metastaz (mSUVmax) değerlendirildi.

Bulgular: EGFR mutasyonu kadınlarda ve sigara içmeyenlerde daha sık bulundu. tSUVmax, EGFR-pozitif hastalarda EGFR-negatif hastalara göre daha düşük olan tek PET parametresiydi (8,7'ye 11) ve p değeri 0,032 idi. nSUVmax ve mSUVmax sonuçları ile EGFR mutasyonu arasında fark yoktu. tSUVmax, nSUVmax ve mSUVmax, KHDAK'de ALK pozitif ve ALK negatif gruplar arasında anlamlı olarak farklı değildi. Tanı anında plevral sıvının varlı̆̆ı, pozitif ALK ekspresyonu ile anlamlı olarak ilişkiliydi.

Sonuç: Düşük tSUVmax ve primer tümör çapının mutant EGFR durumu ile ilişkili olduğunu ve EGFR testi olmayan bazı KHDAK hastalarında EGFR mutasyon durumundaki ayrımı artırmak için diğer klinik faktörlerle değerlendirilebileceğini gösterdik. ALK pozitifliği ile plevral sIVI varlı̆̆ı arasında bir ilişki vardı. ALK pozitifliğ̈inin sadece adenokarsinom grubunda ve daha genç yaşta olabileceğini de belirttik.

Anahtar kelimeler: Epidermal büyüme faktörü reseptörü; anaplastik lenfoma kinaz; mutasyon; küçük hücreli dışı akciğer kanseri; pozitron emisyon tomografisi

\section{INTRODUCTION}

Lung cancer is the most frequent reason of cancer-related mortality in the whole world. Surgery, radiotherapy, systemic platinum-based combination chemotherapy, and biological thereapies are employed in the treatment of lung cancer (1). Understanding lung cancer biology and molecular changes involved in the carcinogenesis of lung cancer has led to the development of new medications targeting oncogenesis, specifically tumor suppressor genes, growth factor receptors or angiogenesis. This method aims to provide a more effective treatment with fewer side effects by targeting a specific molecule to stop tumor growth.

Although there are no target-specific treatments for each cancer type, several therapies have been included in standard practice. Main molecular changes that may be targeted in NSCLC are epidermal growth factor receptor (EGFR) mutation, Anaplastic Lymphoma Kinase (ALK) translocation and "proto-oncogene tyrosine-protein kinase ROS-1 translocation (2). Multifactorial oncogenes like Kras, EGRF, PI3K, rough domains or EML4-ALK gene fusion mutations have been shown in previous studies; and if not all, most of them have been shown to be present in adenocarcinomas (3). In other words, new drugs that target a specific pathway and/or population have strong therapeutic indices, low toxicitie, and ensure that the patient population that will benefit most from the treatment is selected. These advantages may be achieved especially with therapies intended for tyrosinkinase inhibitor (TKI) (erlotinib and gefinitib) or for ALK (4-7). However, it is difficult to obtain the tumor tie on which sufficient and good-quality mutation examination is possible, and such tests are not yet applicable everywhere.

Positron emission tomography (PET) is a molecular imaging method, which provides physiological information needed for clinical diagnosis based on change in tissue metabolism. Then oncologic PET applications became widespread with the development of computed tomography (CT) and integrated PET scanners (PET/CT). Among the most common PET/CT applications, there are lung cancers. Today, FDG PET/ CT is used for diagnosis, staging and evaluation of response to treatment, re-staging, radiotherapy planning and deteriming prognosis in lung cancer. With PET that is applied with fluoro-2-deoxy glucose (FDG) marked with F-18 isotope, many malignant tumors might be visualized as noninvasive due to increased glucose metabolism. FDG PET decreases the glucose metabolism pathway of the EGFR signal 
and lactate production of the EGFR-TKIs and glucose consumption in cells that have EGFR mutation $(1,7-$ 13). In this way, FDG involvement in PET/CT might be useful as a noninvasive marker in predicting EGFR mutation and ALK rearrangement8. The data in the literature that examine the relation between the presence of EGFR mutation and FDG involvement in lung cancer differ, and there are several studies examining the relation between glucose metabolism and ALK rearrangement $(9,14,15)$.

In this study, the relation between FDG involvement changes, genetic mutation status and clinical parameters were evaluated retrospectively in lung cancer patients who had been studied in our clinic since 2014 and whose genetic mutation examinations were made in our clinic. These genetic tests are both expensive and tissue required. Therefore, we investigated whether the Suv (max) value in 18F-FDG could help predict EGFR mutation or ALK positivity. We also investigated whether 18F-FDG PET is a valuable non - invasive method in estimating EGFR mutation and ALK positivity in NSCLC.

\section{MATERIALS and METHODS}

\section{Patients and Inclusion Criteria}

We retrospectively reviewed 232 NSCLC patients whose histopathological diagnosis and mutation results were reached between 2014 and 2018. Due to tissue insufficiency, both EGFR and ALK could not be measured in 14 cases. A total of 104 cases were excluded from the study due to the absence of prediagnosis PET/CT scan, or if the time interval between sampling and PET/CT exceeded 1 month. Therefore, a total of 114 patients with at least one of EGFR or ALK that could be tested with enough size of sampling were included in this study (Figure 1). Patient

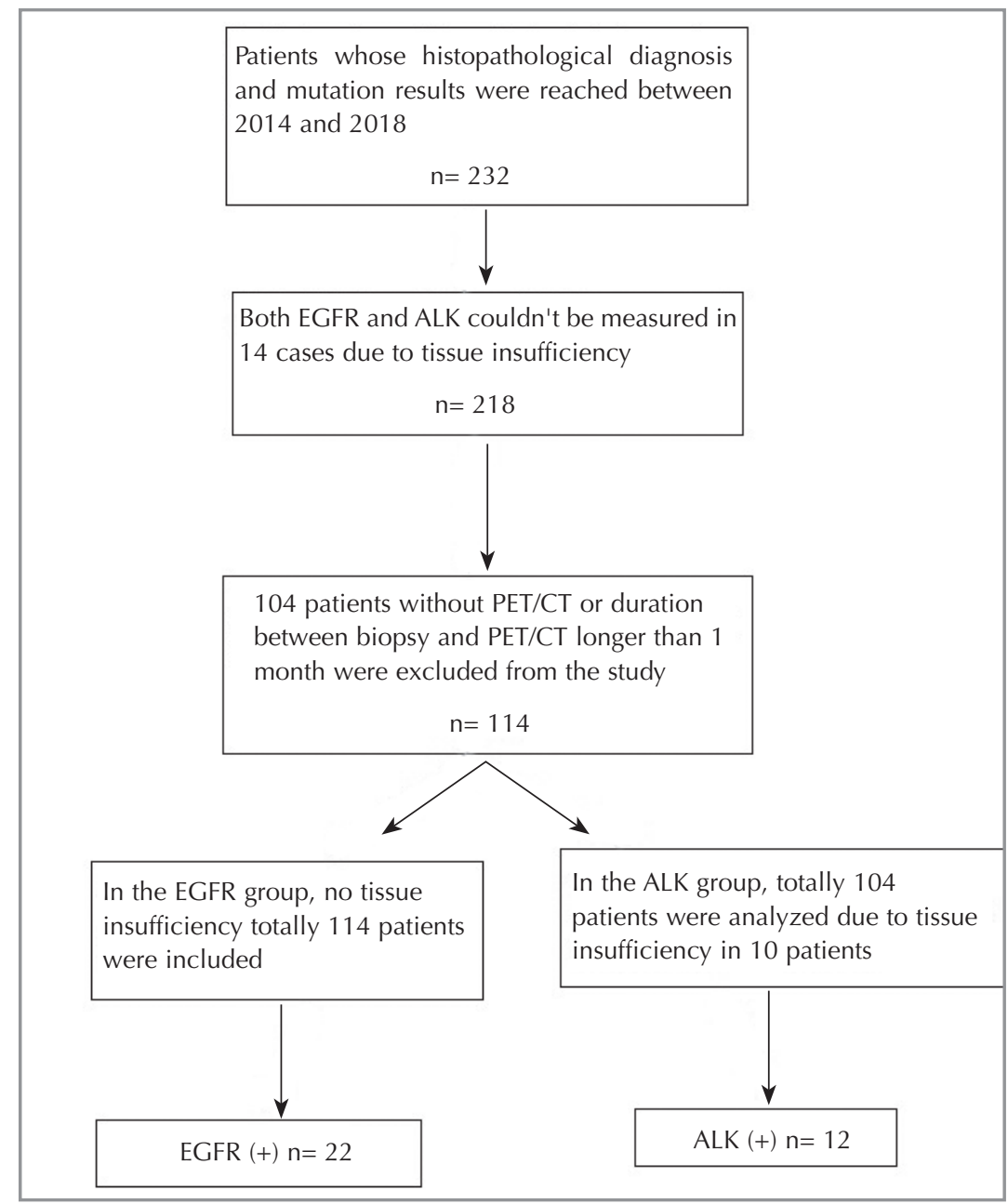

Figure 1. Follow chart of the patients in the study. 
clinical characteristics including age, sex, smoking history, histopathology, tumour size, nodal involvement, distant metastasis and tumour stage were recorded. The differences in several clinical characteristics and three parameters based on 18F-FDG $\mathrm{PET} / \mathrm{CT}$, [including the maximal standard uptake value (SUVmax) of the primary tumour (tSUVmax), the one with highest SUV uptake lymph node (nSUVmax) and distant metastasis (mSUVmax)] between EGFR and ALK subgroups were analysed. Also, when one of the ALK rearrangement or EGFR mutation analyses was not studied due to insufficient tissue, those cases were not included in the statistical analysis of that group.

\section{F-FDG PET/CT Acquisition and Analysis}

All patients involved in the study underwent wholebody 18F-FDG PET/CT scanner (GEMINI TF 16 Slice, by Philips Healthcare, Koninklijke Philips Electronics N.V, Amsterdam). PET component is a high-resolution scanner with a spatial resolution of $4.7 \mathrm{~mm}$ and has no septa, thus allowing 3-dimensional-only acquisitions. CT portion of the scanner is 16 -slices. After fasting for at least six hours before the integrated PET/CT examination, blood glucose level of the patient was obtained prior to tracer injection. In case blood glucose level for FDG injection was below 180 $\mathrm{mg} / \mathrm{dL}, 3 \mathrm{MBq}$ of $18 \mathrm{~F}$-FDG per kilogram of body weight was injected. After the injection, the patients rested for a period of about $60 \pm 10$ minutes in a comfortable room and chair. Tomography images were acquired for attenuation correction and anatomic localization, PET images were acquired in axial planes from the proximal femur to the vertex, 9-11 bed in 2 minutes per bed. Processed images were displayed in coronal, transverse, and sagittal planes and PET/CT images were also assessed quantitatively using the maximum standardized uptake value (SUVmax). All PET/CT data were reviewed by an experienced nuclear medicine physician. The lesions which were over SUVmax 2.5 were considered as pathological.

\section{EGFR Mutation Analysis}

EGFR mutation analysis was performed using tissue specimens from biopsy or surgical excision.

DNA isolation was carried out from the paraffin blocks of the patients (at least 3 sections of ca. $5 \mu$ per patient) using the "QIAamp ${ }^{\circledR}$ DNA FFPE Tissue kit" (Qiagen, the USA) at 15-20 ng per reaction tube. For mutation screening, "Easy ${ }^{\circledR}$ EGFR" (Diatech, Italy) kit was used. In the first stage of the study, $10 \mu \mathrm{l} \mathrm{Taq}$ Premix 920, $4 \mu \mathrm{l}$ Water and $1 \mu \mathrm{l}$ EGFR ctrl mix were prepared, and pipettage and spin centrifuge were carried out. In the mutation detection step, 8 different mixtures were prepared and reproduced as EGFR G719x, EGFR T790M, EGFR S768I, EGFR ex20ins, EGFR L858R, EGFR L861Q, EGFR ex19del and EGFR ctrl. Distilled water was added for negative control and EGFR Pos. Ctrl II was added to the study for positive control. The RT-PCR stage was carried out with the Rotor gene system. Evaluation at the analysis stage was carried out by calculating the $\Delta \mathrm{Ct}$ values according to the recommendations of the manufacturer, as written in the evaluation kit.

\section{ALK Rearrangement Analysis}

Genetic alterations were tested using tissue specimens obtained from biopsy or surgical excision. For ALK rearrangement, fluorescence in situ hybridization (FISH) was performed on tissue specimen. Approved DAKO ALK Break apart FISH Probe Kit was used for molecular testing. Paraffin sections from tumour block ranging between 4-6 $\mu \mathrm{m}$ thickness were deparaffinized with special solutions in the Kit, unstained and hybridized overnight with the ALK probe, and were then evaluated by dual filtered microscopy. An ALK translocation was regarded as positive when separated red and green fluorophores or single red signals were observed in $>15 \%$ of tumour cells in investigation of more than 50 tumour cells.

\section{Statistical Analysis}

SPSS for Windows ${ }^{\circledR} 20.0$ was used for statistical analyses. Descriptive statistics were expressed as mean \pm standard deviation or median $(25 \%-75 \%)$ for continuous variables and as frequency (\%) for categorical variables. Pearson's Chi-square test was used to determine the association between the categorical variables. Mann-Whitney $U$ test were used to compare descriptive values of a continuous variable between two groups. $p<0.05$ was assumed to be statistically significant. Receiver operating characteristics (ROC) curves were constructed to obtain the cut-off value of the primary tumour SUVmax (tSUVmax) for predicting the EGFR mutations status. Logistic regression analysis was performed to identify independent predictors of the EGFR or ALK status. Univariate analyses were performed before the regression model was formed. The variables that were statistically significant $(p<0.05)$ and those with $p$ val- 
ues of 0.25 and below were taken. Age (years), sex (male/female), smoking status (smoking/non-smoking), presence of cancer in the family (no/yes), primary tumour SUV value (tSUVmax), mediastinal lymph node SUV (nSUVmax) and metastasis (mSUVmax) were included. Statistical significance level was determined as $p<0.05$ and removal $p<0.10$. Multivariate logistic regression analysis was performed to determine the predictors of EGFR mutations and ALK positivity. The odds ratios and 95\% confidence intervals of the predictors were obtained. The last step was presented in logistic regression analysis.

\section{Ethics Statement}

The present study protocol was reviewed and approved by the local committee of Health Sciences University İzmir Dr. Suat Seren Chest Diseases and Chest Surgery
Training and Research Hospital (approval no: 49109414-806.02.02). Informed consent was submitted by all subjects when they were enrolled.

\section{RESULTS}

\section{Patient Characteristics}

In the EGFR group, there was no tissue insufficiency. However, in the ALK group, a total of 104 patients were analyzed due to tissue insufficiency in 10 patients. Out of a total of 114 NSCLC patients, 29 were females $(25.50 \%)$ and 85 were males $(74.50 \%)$ with a mean age of $58.51 \pm 10.38$ years. were included in the study. General characteristics of the patients are shown in Table 1 . The most frequent mutations were exon 19 (53.33\%) and L858R exon $21(33.33 \%)$ mutations (Figure 2$)$.

\section{Table 1. The characteristics of 114 patients}

\begin{tabular}{|c|c|c|}
\hline Characteristics & $\mathbf{n}$ & $\%$ \\
\hline \multicolumn{3}{|l|}{ Gender } \\
\hline Female & 29 & 25.5 \\
\hline Male & 85 & 74.5 \\
\hline \multicolumn{3}{|l|}{ Nodal Involvement } \\
\hline Absent & 41 & 35.65 \\
\hline 1 & 16 & 13.91 \\
\hline 2 & 7 & 6.09 \\
\hline$>2$ and bulky & 50 & 44.35 \\
\hline Smoking History & - & - \\
\hline Ever-smoker & 84 & 73.92 \\
\hline Never-smoker & 30 & 26.09 \\
\hline \multicolumn{3}{|l|}{ Histopathology } \\
\hline Adenocarcinoma & 105 & 92.17 \\
\hline Squamous & 7 & 6.09 \\
\hline Other & 2 & 1.74 \\
\hline \multicolumn{3}{|l|}{ Stage } \\
\hline Stage 1 & $\begin{array}{l}y \\
6\end{array}$ & $\begin{array}{l}7.03 \\
5.22\end{array}$ \\
\hline Stage 2 & 31 & $\begin{array}{c}5.22 \\
26.98\end{array}$ \\
\hline Stage 3 & 68 & 60.00 \\
\hline Stage 4 & & \\
\hline \multicolumn{3}{|l|}{ Metastasis } \\
\hline Absent & 45 & 39.13 \\
\hline Present & 69 & 60.87 \\
\hline \multicolumn{3}{|l|}{ Mutation } \\
\hline Absent & 80 & 70 \\
\hline Present & 34 & 30 \\
\hline \multicolumn{3}{|l|}{ EGFR (114 patients) } \\
\hline Negative & 92 & 80.70 \\
\hline Positivity & 22 & 19.30 \\
\hline \multicolumn{3}{|l|}{ ALK (*104 patients) } \\
\hline Negative & 92 & 80.7 \\
\hline Positivity & 12 & 10.5 \\
\hline Insufficient tissue and/or failure to receive signal & 10 & 8.7 \\
\hline
\end{tabular}




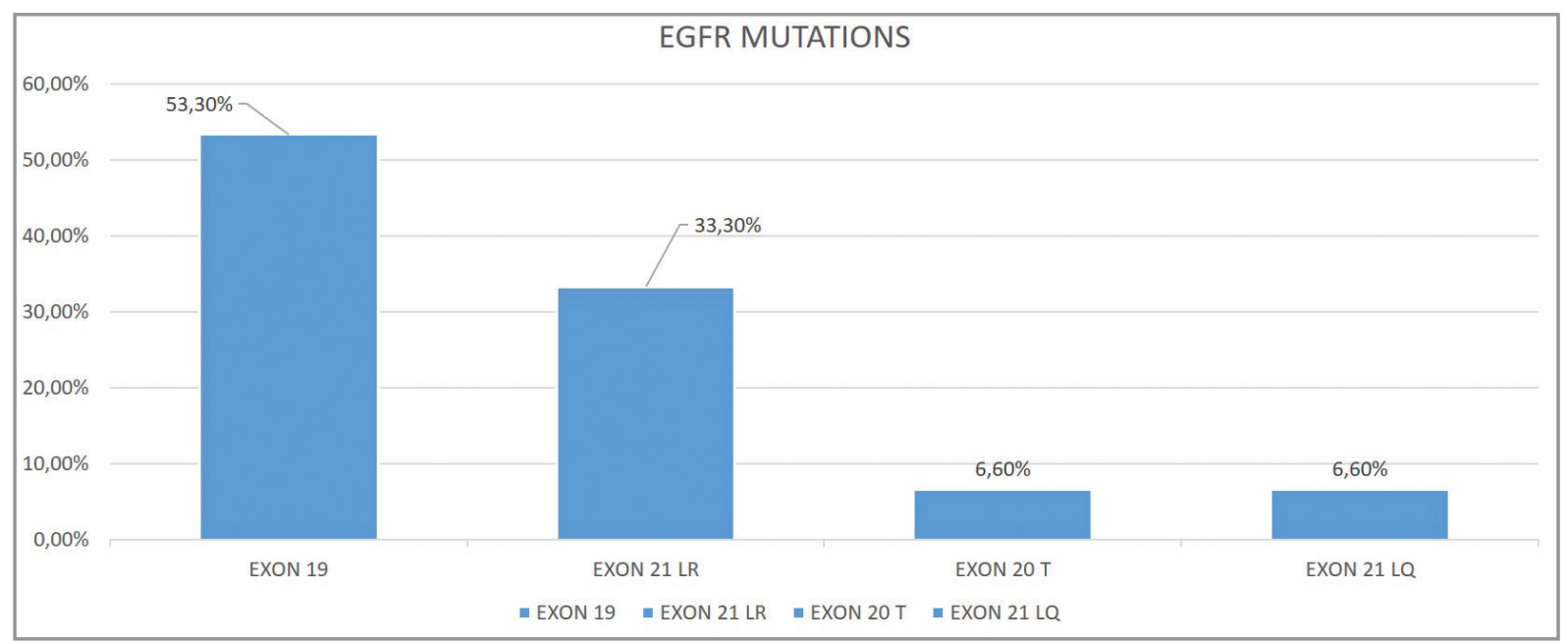

Figure 2. Frequency of EGFR mutations.

Table 2. Association between clinical characteristics, PET/CT parameters and EGFR, ALK, ROS status in NSCLC patients

\begin{tabular}{|c|c|c|c|c|c|c|}
\hline & \multicolumn{2}{|c|}{ EGFR (114 patients) } & \multirow[b]{2}{*}{ p } & \multicolumn{2}{|c|}{ ALK $(* 104$ patients $)$} & \multirow[b]{2}{*}{ p } \\
\hline & Negative & Positive & & Negative & Positive & \\
\hline Age & $57.56 \pm 9.95$ & $61.77 \pm 11.96$ & 0.09 & $59.30 \pm 10.15$ & $50.67 \pm 10.63$ & 0.019 \\
\hline $\begin{array}{l}\text { Gender } \\
\quad \text { Female } \\
\text { Male }\end{array}$ & $\begin{array}{l}16 \\
76\end{array}$ & $\begin{array}{r}13 \\
9\end{array}$ & 0.00 & $\begin{array}{l}25 \\
67\end{array}$ & $\begin{array}{c}2 \\
10\end{array}$ & 0.435 \\
\hline $\begin{array}{l}\text { Smoker } \\
\text { Non-smoker }\end{array}$ & $\begin{array}{l}74 \\
18\end{array}$ & $\begin{array}{l}10 \\
14\end{array}$ & 0.001 & $\begin{array}{l}73 \\
19\end{array}$ & $\begin{array}{l}6 \\
6\end{array}$ & 0.025 \\
\hline $\begin{array}{l}\text { Pleural effusion at diagnosis } \\
\text { Absent } \\
\text { present }\end{array}$ & $\begin{array}{l}71 \\
21\end{array}$ & $\begin{array}{c}16 \\
6\end{array}$ & 0.615 & $\begin{array}{l}75 \\
17\end{array}$ & $\begin{array}{l}6 \\
6\end{array}$ & 0.014 \\
\hline $\begin{array}{l}\text { Mediastinal LAP } \\
\quad 0-1 \\
\quad \geq 2 \text {. Bulky }\end{array}$ & $\begin{array}{l}47 \\
45\end{array}$ & $\begin{array}{l}10 \\
12\end{array}$ & 0.668 & $\begin{array}{l}46 \\
46\end{array}$ & $\begin{array}{l}5 \\
7\end{array}$ & 0.587 \\
\hline $\begin{array}{l}\text { Cancer history in family } \\
\text { Absent } \\
\text { present }\end{array}$ & $\begin{array}{l}57 \\
35\end{array}$ & $\begin{array}{c}18 \\
4\end{array}$ & 0.073 & $\begin{array}{l}61 \\
31\end{array}$ & $\begin{array}{l}7 \\
5\end{array}$ & 0.585 \\
\hline $\begin{array}{l}\text { Stage } \\
\text { Stage } 1 \\
\text { Stage } 2 \\
\text { Stage } 3 \\
\text { Stage } 4\end{array}$ & $\begin{array}{c}7 \\
4 \\
23 \\
58\end{array}$ & $\begin{array}{c}2 \\
2 \\
8 \\
10\end{array}$ & 0.314 & $\begin{array}{c}8 \\
6 \\
28 \\
50\end{array}$ & $\begin{array}{l}1 \\
0 \\
2 \\
9\end{array}$ & 0.532 \\
\hline Tumour size & $4.7(3.7)$ & $3.9(1.4)$ & 0.061 & $4.25(3.3)$ & $4.5(3)$ & 0.656 \\
\hline $\begin{array}{l}\mathrm{PET} / \mathrm{BT} \\
\text { tSUV max } \\
\text { nSUV max } \\
\text { mSUV max }\end{array}$ & $\begin{array}{c}11(8.8) \\
10.1(9.8) \\
8(7.2)\end{array}$ & $\begin{array}{l}8.7(6.45) \\
\quad 7(5) \\
6.8(6.2)\end{array}$ & $\begin{array}{l}0.032 \\
0.059 \\
0.201\end{array}$ & $\begin{array}{l}10.9(7.9) \\
8.4(8.7) \\
7.2(5.3)\end{array}$ & $\begin{array}{l}9.9(6.42) \\
8(23.3) \\
6.4(12.5)\end{array}$ & $\begin{array}{l}0.467 \\
0.499 \\
0.799\end{array}$ \\
\hline
\end{tabular}




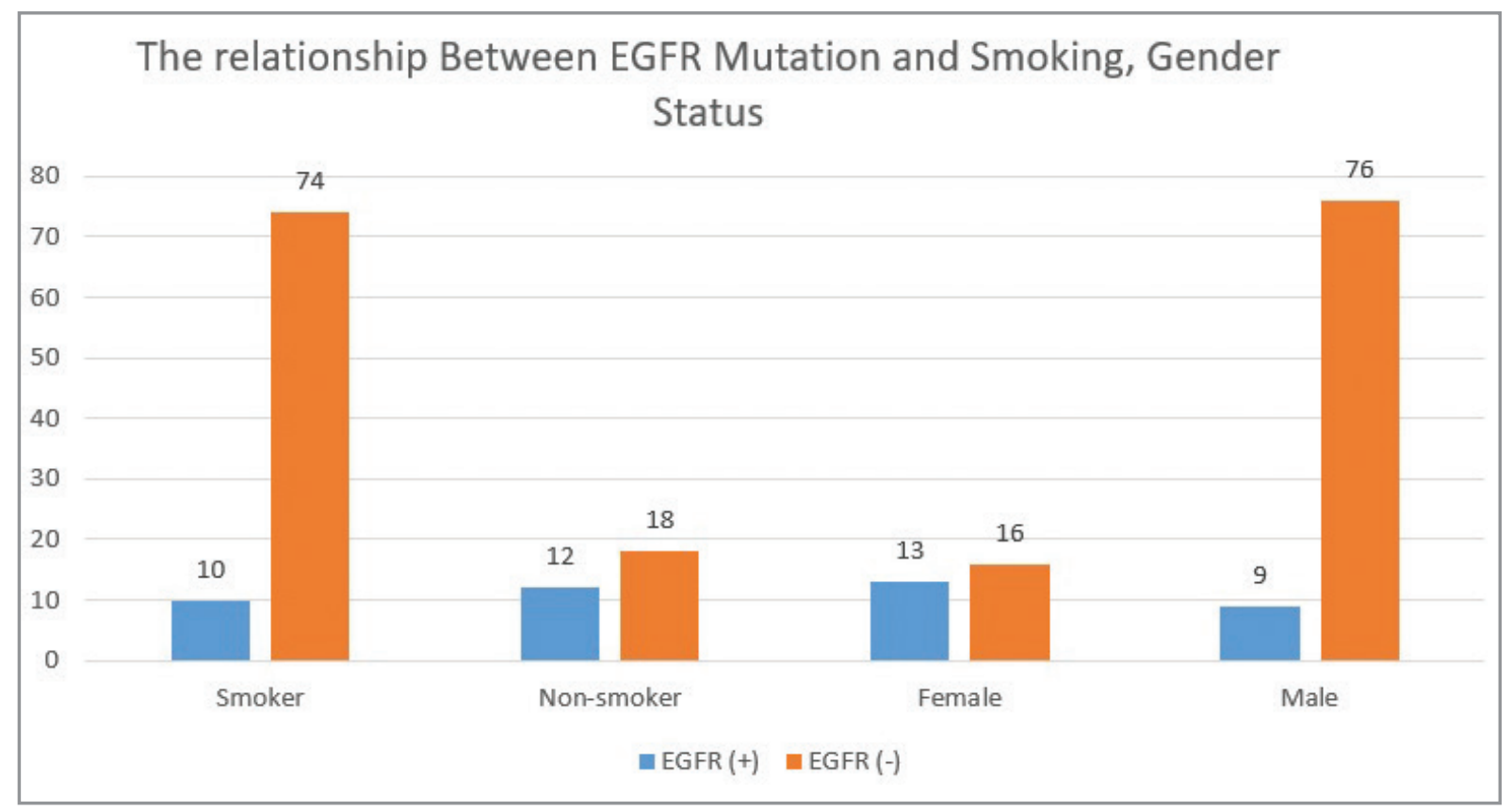

Figure 3. The relationship between EGFR mutation and smoking status and sex.

\section{Association Between Clinical Characteristics, PET/CT Parameters and EGFR, ALK Status in NSCLC Patients}

The clinical characteristics of NSCLC patients are summarized in Table 2 based on their EGFR and ALK status. EGFR mutations were found more frequently in females and non-smokers (p: 0.000, 0,001, respectively) (Figure 3). The patients with ALK-positive NSCLC were younger $(59.30 \pm 10.15$ and $50.67 \pm$ 10.63, $p=0.019$ ), and the rate of ALK positivity was higher in non-smokers $(p=0.025)$ (Table 2). tSUVmax was the only PET parameter that was lower in EGFR-positive patients than in EGFR-negative patients (8.7 vs. 11$)$, with a $p$ value $(0.032)$. There were no differences between mSUVmax, nSUVmax results and EGFR mutation (Table 2). tSUVmax, nSUVmax and mSUVmax were not significantly different between ALK positive and ALK negative groups in NSCLC (Table 2). The presence of pleural fluid at the time of diagnosis was significantly associated with positive ALK expression $(p=0.014)$ (Table 2).

\section{Association Between Clinical Characteristics, PET/ CT Parameters and EGFR and Status in Lung Adenocarcinoma group}

nSUVmax was significantly lower only in the adenocarcinoma subgroup (105 cases) in EGFR mutation positive patients than in EGFR mutation negative patients $(p=0.042)$. Also, tSUVmax was lower in EGFR-positive patients than in EGFR negative patients (5.6 vs. 7.3), with a borderline $p$ value (0.058). No statistically significant difference was found between ALK-positive and ALK-negative patients in terms of tSUVmax, nSUVmax and mSUVmax. In the adenocarcinoma group, as in the NSCLC group, there was a correlation between the presence of pleural fluid and ALK positivity at the time of diagnosis (p: 0.018) (Table 3).

\section{Prediction of the EGFR Mutation Status}

ROC curve analysis revealed that the cut-off point for the tSUVmax was $\leq 14.7 ; 95.4 \%$ sensitivity, $31.8 \%$ specificity, $25.3 \%$ positive predictive value (PPV), $96.7 \%$ negative predictive value (NPV) were achieved, and the area under curve (AUC) was $0.648(95 \% \mathrm{Cl}$, 0.553-0.736) with $\mathrm{p}=0.001$ (Figure 4).

In multivariate analysis, being female increased the risk of EGFR mutation 4.9 times. A one-unit increase in the primary tumor SUVmax value reduced the risk of genetic mutation at a rate of $14 \%$. These risk changes were found to be statistically significant $(p<$ 0.05) (Table 4).

\section{DISCUSSION}

In the present study, we evaluated the clinical significance of $18 \mathrm{~F}-\mathrm{FDG}$ uptake as a predictor of the pres- 
Table 3. Association between clinical characteristics, PET/CT parameters and EGFR, ALK status in lung adenocarcinoma group

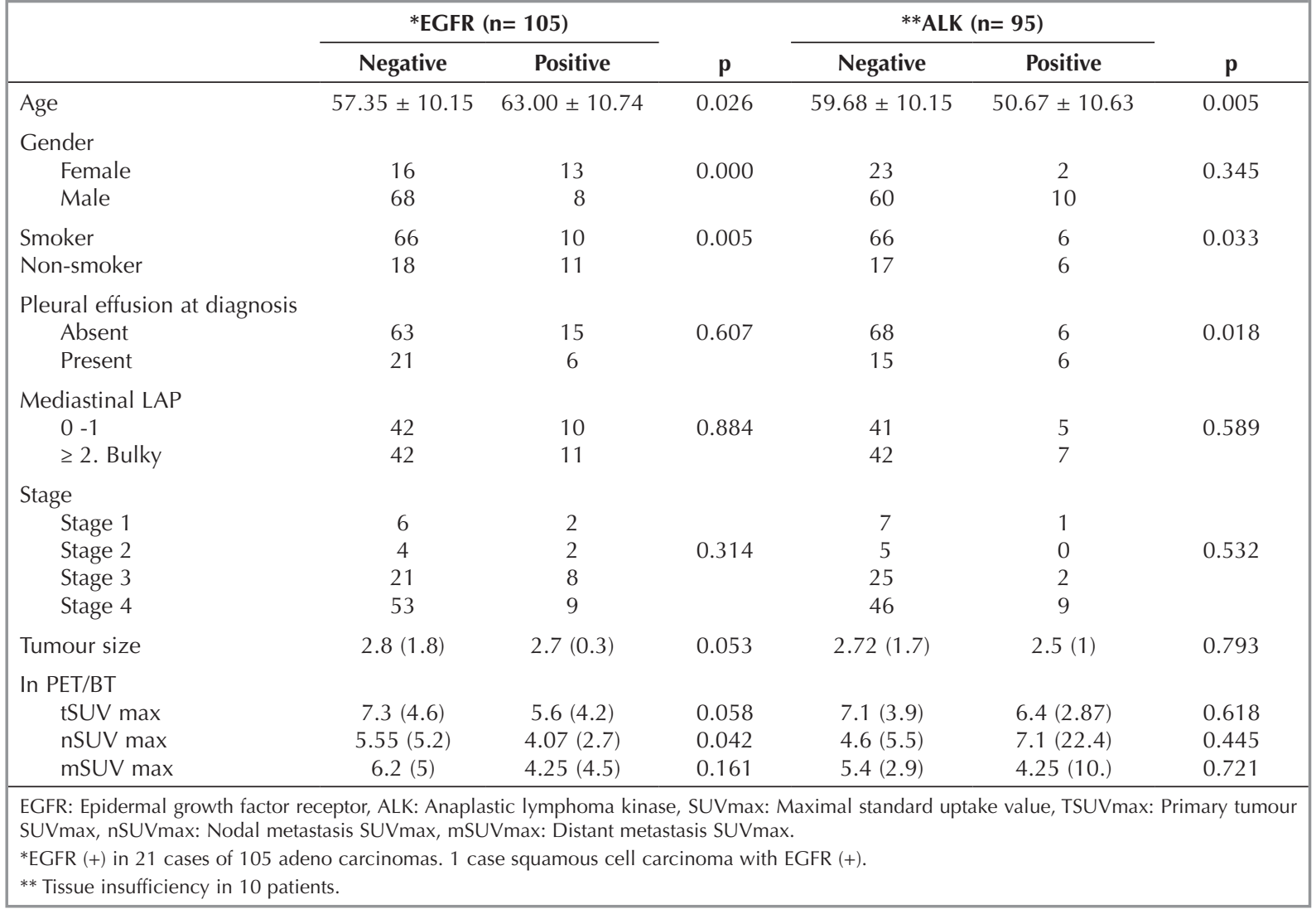

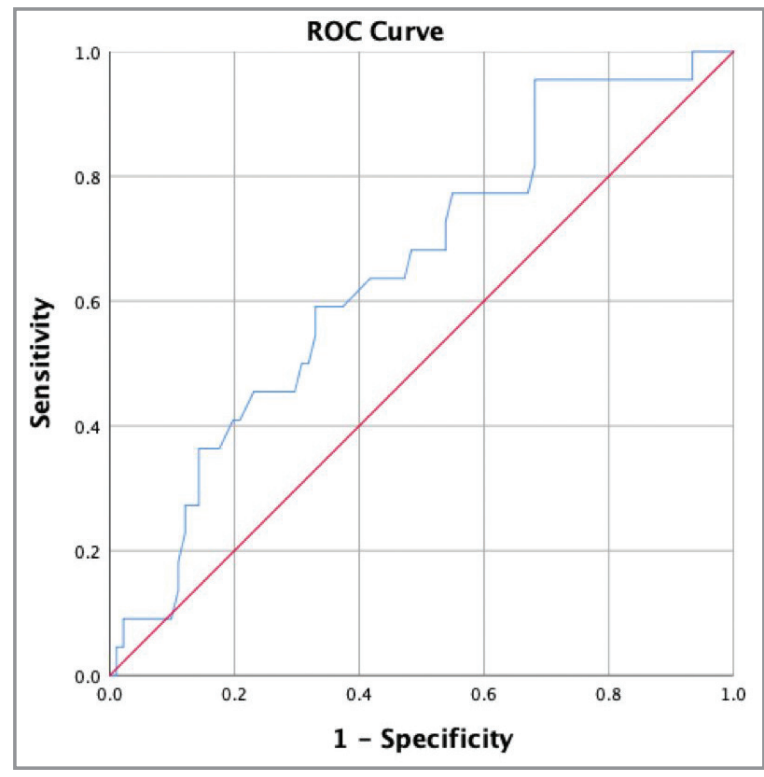

Figure 4. Receiver operating characteristic curves of primary tumour SUVmax for predicting EGFR mutation. ence of the EGFR mutations and ALK rearrangement. Similar to previous studies, EGFR mutation was found more frequently in females, non-smokers, and in adenocarcinomas. And also, EGFR mutation was found to be associated with quantitative measurements of 18F-FDG uptakes (i.e., SUVs). We observed that patients with low SUVs in primary tumours (tSUVmax s14.7) harboured a higher incidence of EGFR mutation, when compared with those with high SUVs. Importantly, multivariate analysis confirmed that tSU$\checkmark$ max and female sex were predictive factors for the presence of EGFR mutation. The presence of pleural fluid at the time of diagnosis was significantly associated with positive ALK expression.

Our results agree with previous studies that show that EGFR mutations are found predominantly in female patients, in patients with adenocarcinoma histology, and in never-smokers $(8,16,17)$. While in Europe, EGFR mutation incidences changes between 6\% and $24 \%$; in Asia, this rate is $51.3 \%$ (14). In a study con- 
Gayaf M, Anar C, Aksel N, Erbaycu AE, Koporal H.

Table 4. Multivariate regression analysis for factors associated with EGFR mutation in patients with NSCLC

\begin{tabular}{|lcccc|}
\hline & Beta & $\mathbf{p}$ & OR & $\mathbf{\% 9 5} \mathbf{C I}$ \\
\hline Gender & & & & \\
$\quad$ Male & 1 & & 4.93 & $1.60-15.33$ \\
$\quad$ Female & 1.596 & 0.006 & 1.05 & $0.99-1.11$ \\
Age & 0.048 & 0.089 & 0.86 & $0.76-0.99$ \\
tSUVmax & -0.142 & 0.039 & & \\
\hline
\end{tabular}

ducted with patients diagnosed with adenocarcinoma by Kanmaz et al. in Turkey, EGFR mutation rate has been reported as 28\%; however, this rate has been found to be $13.5 \%$ in the pateints diagnosed with NSCLC in a multicenter REDIGMA study conducted in Turkey. Na et al. have conducted a study in Korea and reported that EGFR mutation rate was 21\% in patients with NSCLC. Cho et al. have reported a $50 \%$ rate in patients diagnosed with adenocarcinoma $(14,16,17)$. In our study, on the other hand, most patients were diagnosed with lung adenocarcinoma, and EGFR mutation frequency was found to be $19.65 \%$ in the study group. Our results are similar to European data and were found to be lower than the results reported in Asian studies. This can be explained by ethnic differences.

The data from previous studies that have investigated the value of $18 \mathrm{~F}-\mathrm{FDG}$ PET for predicting EGFR status are conflicting. In a retrospective study conducted by Zhilei et al. (8), 849 Chinese NSCLC patients have been examined, and other studies conducted by $\mathrm{Na}$ et al. (16) and Cho et al. (17), Guan et al. (9) have reported that the presence of EGFR mutation in NSCLC was associated with low SUVmax (tSUVmax) in primary tumor; and that low tSUV max was an independent variable for the EGFR mutation. Mak et al. (11) have found that an SUVmax value higher than 5 was associated with cases having no EGFR mutation. In our study, we determined that low tSUV max value was associated with EGFR mutation according to the 18-FDG PET BT value in patients diagnosed with NSCLC. However, there are various studies with contrary findings reporting an association between high FDG uptake and an EGFR mutation. Huang et al. (13) have shown that patients with SUVmax $\geq 9.5$ were more likely to have EGFR mutations than those with SUVmax $<9.5$, and Ko et al. (18) have found that a higher SUVmax $(\geq 6)$ is associated with EGFR mutation. Similarly, Kanmaz et al. (14) have found a positive association between high SUVmax values and EGFR mutation. The reason of having such different results may be related to the different histological types of tumours included in those studies. The ratio of bronchoalveolar carcinoma cases known to have a low SUV max involvement is high in the study conducted by Mac et al. (28/90; $25 \%)(11)$. In the study of $\mathrm{Na}$ et al. (16), $44 \%$ of the cases have been diagnosed with squamous cell carcinoma. Different tumour biology may have caused different FDG involvements. In our study, there were four bronchoalveolar carcinoma cases, seven squamous cell carcinomas and 2 different cell types including one neuroendocrine differentiated large cell and one malign epithelial tumour. Lee et al. (12) have revealed that tSUVmax was statistically significant only in the univariate regression analysis but not in the multivariate regression analysis. Our results

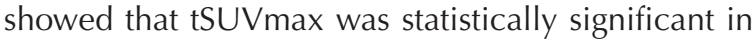
the multivariate regression analysis. Moreover, SUVmax AUC value for EGFR positivity was found to be 0.648 by ROC analysis. Also, in our study, the cutoff point for the tSUVmax was $\leq 14.7$ with $95.4 \%$ sensitivity, $31.8 \%$ specificity, $25.3 \%$ positive predictive value (PPV), and $96.7 \%$ negative predictive value. In another study in which, 731 patients with adenocarcinoma and 77 with non-adenocarcinoma were enrolled, conducted by Zhilei Lv et al., ROC curve analysis have revealed that the cut-off point for the tSUVmax was 7.0 with $72.8 \%$ sensitivity, $38.5 \%$ specificity, a $54.6 \%$ positive predictive value, a $58.2 \%$ negative predictive value, and $57.1 \%$ accuracy were achieved, and the area under curve (AUC) was 0.557 (8). Guan et al. have shown that SUVmax cut-off point was 8.1 and AUC was 0.65 [95\% Confidence Interval (Cl) 0.60-0.72].

In lung adenocarcinoma, primary tumor diameter tends to be smaller than other NSCLC subtypes. In our study, the average diameter of the primary tumor was determined as 2.7 in the adenocarcinoma group $(n=105)$. No correlation was detected between EGFR mutation and tumor diameter. In our study group, among the 114 patients who had NSCLC, 105 
patients were diagnosed with adenocarcinoma. Only one of the patients who had squamous cell carcinoma had EGFR mutation. For this reason, our results might not have been found to be significant in terms of primary tumor diameter because of the homogeneity of the group. Guan et al. (9) have found a strong negative correlation between primary tumour size and EGFR mutations. Large primary tumour size $(\geq 5$ $\mathrm{cm})$ was significantly associated with wild-type EGFR.

Recently, a new oncogene called "akinoderm microtubule-associated protein-like 4(EML4)-anaplastic lymphoma kinase (ALK) fusion oncogene" has been defined in lung adenocarcinomas It is not found frequently in lung adenocarcinomas (15-20). Dramatic response and a long progression-free survival might be achieved in patients with ALK rearrangement with the target-specific treatment $(8,21)$.

Choi et al. have found a rate of $5.4 \%$ ALK rearrangement in 331 lung adenocarcinomas. Zhilei et al. (8) have investigated the metabolic features of 17 ALK positiveness in 223 NSCLC patients (7.6\%) and 17 ALK positiveness in 190 adenocarcinoma subgroup patients $(8.9 \%)$ ALK positiveness was found to be $11.5 \%$ in our study. Among the adenocarcinoma patients, nSUVmax was higher in the ALK-positive group than in the ALK-negative group. However, there was no difference in tSUVmax between the two groups. Jeong et al. (22) have reported that a higher tSUVmax was an independent predictor of ALK positivity. In our study, ALK rearrangement was statistically significant only in the young age and adenocarcinoma group and in the non-smokers $(p=0.005, p=$ 0.033, respectively). We also found that ALK positivity was present only in the adenocarcinoma group. No statistically significant differences were detected between ALK-positive patients and ALK-negative patients in the case of adenocarcinoma in terms of neither SUVmax nor nSUVmax and mSUVmax. The reason for this may be associated with the fact that 53 ALK positive patients who received pre-treatment were reported in Jeong's study; however, ALK positive patients were low in number in our study $(n=12)$. In another study, ALK-positive group demonstrated higher SUVmax, which suggests that ALK positivity is related with more malignant features with higher glucose metabolism. Additionally, higher tumour stage and more common metastases to lymph nodes have been observed in ALK positive group (15).
Higher FDG uptake of ALK positive group may have correlations with radiological phenotype and genetic interactions. In previous studies, ALK-rearranged lung cancer has exhibited solid pattern rather than groundglass opacity (GGO) pattern on CT, whereas EGFR mutated tumours have been associated with high proportion of GGO $(23,24)$. It has been reported that less aggressiveness of lung adenocarcinoma is related with lower FDG uptake and higher proportion of GGO (25). In our study, we found a correlation between ALK positivity and the presence of pleural fluid in adenocarcinoma group. However, we did not look at the relationship between ALK, EGFR mutation and other radiological findings (consolidation, GGO, nodule, etc.), which were detected in imaging methods.

This study has several limitations. Firstly, the design of this study was retrospective, and selection bias may have existed. Secondly, the patient population was not large enough for sufficient statistical significance and subgroup analysis.

\section{CONCLUSION}

This study presented the association of the presence of EGFR mutations with PET findings in patients with NSCLC. We showed that low tSUVmax was associated with mutant EGFR status and could be evaluated with other clinical factors to increase discrimination in EGFR mutation status in some NSCLC patients without EGFR testing. If a patient does not respond well to other treatments and cannot undergo gene testing, clinical factors (female, non-smokers) and low tSUVmax ( $\leq 14.7)$ might be helpful for assessing EGFR mutation status. This may determine whether to use EGFR-TKI or not. We also noted that ALK positivity might be only in the adenocarcinoma group and at a younger age. In addition, we found a correlation between ALK positivity and the presence of pleural fluid.

Ethical Committee Approval: This study approval was obtained from İzmir Dr. Suat Seren Chest Diseases and Chest Surgery Training and Research Hospital Ethical Committee (Decision No: 49109414806.02.02, Date: 19.01.2018).

\section{CONFLICT of INTEREST}

The authors declare that they have no conflict of interest. 


\section{AUTHORSHIP CONTRIBUTIONS}

Concept/Design: MG, CA, NA

Analysis/Interpretation: MG, CA, AEE

Data acqusition: $M G, N A, H K$

Writing: CA, MG, AEE

Clinical Revision: CA, MG, AEE

Final Approval: All of authors

\section{REFERENCES}

1. Karapolat i. FDG PET/CT Imaging to Evaluate Treatment Response in Lung Cancer. Nucl Med Semin 2018: 43-51.

2. Oyan B. Targetted Therapies in Lung Cancer. Turkiye Klinikleri J Med Oncol-Special Topics 2016: 9(2): 1-13.

3. Heist RS, Sequist LV, Pujol IL. Genetic changes in squamous cell lung cancer. A review. I Thoracic Oncology 2012; 7: 924-33.

4. Shaw AT, Kim DW, Nakagawa K, Seto T, Crinó L, Ahn MJ, et al. Crizotinib versus chemotherapy in advanced ALKpositive lung cancer. N Engl J Med 2013; 368: 2385-94.

5. Lindeman NI, Cagle PT, Beasley MB, Chitale DA, Sanja D, Giuseppe $G$ et al. Molecular testing guideline for selection of lung cancer patients for EGFR and ALK tyrosine kinase inhibitors: guideline from the College of American Pathologists, International Association for the Study of Lung Cancer, and Association for Molecular Pathology. I Mol Diagnostics: JMD 2013; 15: 415-53.

6. Leighl NB, Rekhtman N, Biermann WA, Huang A, MinoKenudson M, Suresh SR et al. Molecular testing for selection of patients with lung cancer for epidermal growth factor receptor and anaplastic lymphoma kinase tyrosine kinase inhibitors: American Society of Clinical Oncology endorsement of the College of American Pathologists/ international association for the study of lung cancer/ association for molecular pathology guideline. I ClinOncol: Off J Am Soc Clin Oncol 2014; 32: 3673-9.

7. Makinoshima H, Takita M, Matsumoto S, Yagishit T, Satoshi $O$, Hiroyasu $E$ et al. Epidermal growth factor receptor (EGFR) signaling regulates global metabolic pathways in EGFR-mutated lung adenocarcinoma. I Biol Chem 2014; 289: 20813-23.

8. Lv Z, Fan J, Xu J, Wu F, Huang $Q$, Guo $M$ et al. Value of 18F-FDG PET/CT for predicting EGFR mutations and positive ALK expression in patients with non-small cell lung cancer: a retrospective analysis of 849 Chinese patients. European Journal of Nuclear Medicine and Molecular Imaging 2018; 45: 735-50.

9. Guan J, Xiao NJ, Chen M, Wen LZ, Zhang YW, Wang S, et al. 18F-FDG uptake for prediction EGFR mutation status in non-small cell lung cancer. Medicine 2016; 95(30):e4421.
10. De Rosa V, lommelli F, Monti M, Fonti R, Votta G, Stoppelli $M P$, et al. Reversal of Warburg effect and reactivation of oxidative Phosphorylation by differential inhibition of EGFR signaling pathways in non-small cell lung cancer. Clin Cancer Res: Off J Am Assoc Cancer Res 2015; 21:5110-20.

11. Mak RH, Digumarthy $S R$, Muzikansky A, Engelman $J A$, Shepard JAO, et al. Role of 18F-fluorodeoxyglucose positron emissiontomography in predicting epidermal growth factor receptor mutations in non-small cell lung cancer. Oncologist 2011; 16: 319-26.

12. Lee $E Y$, Khong $P L$, Lee $V H$, Qian $W, Y u X$, Wong MP. Metabolic phenotype of stage IV lung adenocarcinoma: relationship with epidermal growth factor receptor mutation. Clin Nucl Med 2015; 40: e190-5.

13. Huang CT, Yen RF, Cheng MF, Hsu YC, Wei PF, Tsai YJ, et al. Correlation of F-18 fluorodeoxyg/ucose-positron emission tomography maximal standardized uptake value and EGFR mutations in advanced lung adenocarcinoma. Med Oncol 2010; 27: 9-15.

14. Kanmaz ZD, Aras G, Tuncay E, Bahadır A, Kocatürk C, Yaşar ZA, et al. Contribution of 18 Fluorodeoxyglucose positron emission tomography uptake and TTF-1 expression in the evaluation of the EGFR mutation in patients with lung adenocarcinoma. Cancer Biomarkers: Section A Dis Markers 2016; 16: 489-98.

15. Choi H, Paeng JC, Kim DW, Lee JK, Park CM, Kang KW, et al. Metabolic and metastatic characteristics of ALKrearranged lung adenocarcinoma on FDG PET/CT. Lung Cancer 2013; 79: 242-7.

16. Na II, Byun BH, Kim KM, Cheon GJ, Choe DH, Koh JS, et al.18F-FDG uptake and EGFR mutations in patients with non-smallcell lung cancer: a single-institution retrospective analysis. Lung Cancer 2010; 67: 76-80.

17. Cho A, Hur J, Moon YW, Hong SR, Suh YJ, Kim YJ et al. Correlation between EGFR gene mutation, cytologic tumor markers, 18F-FDG uptake in non-small cell lung cancer. BMC Cancer 2016; 16:224.

18. Ko KH, Hsu HH, Huang TW, Gao HW, Shen DH, Chang WC, et al. Value of 18F-FDG uptake on PET/CT and CEA level to predict epidermal growth factor receptor mutations in pulmonary adenocarcinoma. Eur I Nucl Med Mol Imaging 2014; 41: 1889-97.

19. PaoW, Miller V, Zakowski M, Doherty J, Politi K, Sarkaria I et al. EGFR receptor gene mutations are common in lung cancers from "never smokers" and are associated with sensitivity of tumors to gefitinib and erlotinib. Proc Natl Acad Sci U S A. 2014; 101: 13306-11.

20. Soda $M$, Choi $Y L$, Enomoto $M$, Takada $S$, Yamashita $Y$, Ishikawa $S$, et al. Identification of the transforming EML4ALK fusion gene in non-small-cell lung cancer. Nature 2007; 448: 561-6. 
21. Inamura $K$, Takeuchi $K$, Togashi $Y$, Nomura $K$, Ninomiya $H$, Okui $M$, et al. EML4- ALK fusion is linked to histological characteristics in a subset of lung cancers. J Thorac Oncol 2008; 3:13-7.

22. Jeong CJ, Lee HY, Han J, Jeong IY, Lee KS, Choi YL, et al. Role of imaging biomarkers in predicting anaplastic lymphoma kinasepositive lung adenocarcinoma. Clin Nucl Med 2015; 40: e34-9.

23. Fukui T, Yatabe Y, Kobayashi Y, Tomizawa K, Ito S, Hatooka $S$ et al. Clinico radiologic characteristics of patients with lung adenocarcinoma harboring EML4-ALK fusion oncogene. Lung Cancer 2012; 77: 319-25.
24. Park EA, Lee HJ, Kim $Y T$, Kang $C H$, Kang $K W$, Jeon $Y K$, et al. EGFR gene copy number in adenocarcinoma of the lung by FISH analysis: investigation of significantly related factors on CT,FDG-PET, and histopathology. Lung Cancer 2009; 64: 179-8.

25. Okada M, Tauchi S, Iwanaga K, Mimura T, Kitamura $Y$, Watanabe $\mathrm{H}$, et al. Associations among bronchioloalveolar carcinoma components, positron emission tomographic and computed tomographic findings, and malignant behavior in small lung adenocarcinomas. I Thorac Cardiovasc Surg 2007; 133: 1448-54. 